\title{
Population Dynamics of Phialophora gregata in Stem Residue of a Resistant and a Susceptible Soybean Cultivar
}

\author{
A. E. Impullitti, Former Graduate Research Assistant, and C. R. Grau, Professor, Department of Plant Pathology, \\ University of Wisconsin-Madison, Madison 53706
}

\begin{abstract}
Impullitti, A. E., and Grau, C. R. 2006. Population dynamics of Phialophora gregata in stem residue of a resistant and a susceptible soybean cultivar. Plant Dis. 90:759-764.
\end{abstract}

Previous studies on the saprophytic survival of Phialophora gregata were conducted with soybean residue derived from a susceptible cultivar and did not address genotypes of $P$. gregata. This current study monitored the saprophytic population density of $P$. gregata in stem residue derived from a susceptible and a resistant soybean cultivar placed in the field. A second phase of the study followed the frequencies of genotypes A and B of $P$. gregata in stem residue derived from a susceptible cultivar. The population density of $P$. gregata declined 10-fold in stem residue from the initiation of sampling to the end of this 16-month study, regardless of cultivar or whether residue was positioned on the soil surface or buried. The population density of P. gregata was greater in buried residue of the resistant cultivar compared with the susceptible cultivar after 12 to 14 months, but equalized after 16 months. The population density of $P$. gregata was similar in residue derived from the susceptible and resistant cultivars if positioned on the soil surface. Genotype B was detected more frequently than genotype A of P. gregata at each sampling date regardless of residue placement.

Additional keywords: brown stem rot

Brown stem rot (BSR) of soybean (Glycine $\max (\mathrm{L}$.$) Merr.), caused by Phialo-$ phora gregata (Allington \& Chamberlain) W. Gams $(4,6)$, is an economically limiting disease, and reported to decrease yield in the United States by $1,860 \times 10^{3}$ metric tons per year (27). Crop rotation and soybean cultivars resistant to $P$. gregata have been employed to manage brown stem rot $(1,3,10,19,21,24)$. Soybeans infected with $P$. gregata may express symptoms of chlorosis and necrosis of leaves that can be mistaken as plant senescence (4). Internal browning of vascular and pith tissues that initiates in the lower stem and progresses to the apical meristem is also a prevalent symptom (4). Severity and types of BSR symptoms differ by isolate of $P$. gregata, genotype of soybean accession, inoculum density, and environmental factors $(5,8,9,18,25)$.

Symptoms of BSR and molecular markers initially distinguished $P$. gregata into two different genotypes $(5,9)$, and further studies determined that seven genotypes are present in the north-central United States (8). Plants infected with genotype A expressed interveinal chlorosis and internal

Corresponding author: C. R. Grau

E-mail: cg6@plantpath.wisc.edu

Accepted for publication 18 January 2006

DOI: 10.1094/PD-90-0759

(C) 2006 The American Phytopathological Society stem discoloration, while infection with genotype B (M) resulted in internal stem discoloration and minimal or no foliar symptoms in greenhouse trials $(8,9)$. Plants can be co-colonized with both genotypes, but the frequency of this dual occurrence was reported as low $(5,16)$.

$P$. gregata does not produce a longterm survival structure, and therefore, survival of the pathogen is dependent on its ability to persist as a saprophyte in postharvest soybean residue $(2,12,13)$. It is assumed that the lack of a long-term survival structure contributes to the effectiveness of crop rotation as a means to manage brown stem rot (3). Pathogens that survive in plant residue, such as $P$. gregata, benefit from the slowed decay of crop residue on the soil surface in a no-till (NT) system. Several studies have verified that the severity and occurrence of BSR is greater in systems that allow soybean residue to accumulate on the soil surface compared with systems that incorporate residue into the soil $(3,14,26)$. Research conducted in Wisconsin has shown that the severity of BSR and associated yield loss was correlated with the population density of $P$. gregata in soybean residue (1). The greater severity of BSR reported in shortened crop rotations and NT systems was likely a result of higher inoculum density of $P$. gregata $(1,3)$.

Adee et al. (2) observed that the saprophytic population density of $P$. gregata changed throughout the year in susceptible soybean residue. The saprophytic survival of $P$. gregata in stem residue of susceptible soybean cultivars was greater in residue on the soil surface than buried in the soil (2). Specifically, experiments demonstrated that the saprophytic population density of $P$. gregata increased during the winter months and into the spring and summer in surface residue, while the population density in buried residue increased in the winter and decreased as spring and summer approached (2). The rise in population density during cooler months observed by Adee et al. (2) correlated with laboratory experiments that reported asexual reproduction was greater on water agar and soybean residue when temperatures were between $14^{\circ} \mathrm{C}$ and $21^{\circ} \mathrm{C}(4,7,13)$.

Previous studies have enhanced the understanding of the saprophytic phase of $P$. gregata in susceptible soybean residue. We designed the present study to determine whether the saprophytic population density of $P$. gregata in stem residue derived from resistant cultivars differs from pathogen activity in stem residue derived from susceptible cultivars. Furthermore, it is unknown if the saprophytic survival of genotypes A and B of $P$. gregata differ in soybean residue. An understanding of these mechanisms would refine our understanding of $P$. gregata survival and may enhance control strategies such as crop rotation, cultivar selection, or tillage system. The objectives of this study were to: (i) determine if the saprophytic population density of $P$. gregata differs in residue derived from resistant compared with susceptible soybean cultivars positioned either below or on the soil surface; and (ii) determine whether genotypes $\mathrm{A}$ and $\mathrm{B}$ of $P$. gregata differ in survival in soybean stem residue positioned either below or on the soil surface.

\section{MATERIALS AND METHODS}

Mature stems of the soybean cultivars Bell (BSR-resistant) and Corsoy 79 (BSRsusceptible) were collected from a field naturally infested with $P$. gregata at the West Madison Agriculture Research Station (WMARS), Madison, WI $(10,15,21)$. The cultivars were selected on the basis that they differed in severity of internal stem symptoms, and that Bell was reported to support a predominance of genotype B and Corsoy 79 a predominance of genotype A $(5,16)$. Stems were $40 \pm 5 \mathrm{~cm}$ in length and dried for $48 \mathrm{~h}$. An experimental unit consisted of six 
stems of each cultivar. Two to $3 \mathrm{~cm}$ from each end of the six stems was removed and finely ground using a Cyclone Sample Mill (UDY Corp., Fort Collins, CO). Ground stem tissue was dilution plated within $48 \mathrm{~h}$ after grinding on a semiselective, Phialophora gregata medium (PGM) and incubated for 4 weeks at $12^{\circ} \mathrm{C}$ using methods previously described (2,20). The population density of $P$. gregata was estimated by counting colony forming units (CFU) that formed on the PGM. Remaining ground stem tissue from both cultivars was stored at $4^{\circ} \mathrm{C}$.

The six remaining intact stems were placed in $45 \times 15 \mathrm{~cm}$ nylon mesh bags $(2$ $\mathrm{mm}$ openings) and returned to the field $(2,23)$. The plot location selected at the WMARS did not have a history of soybean production, and therefore, we assumed that $P$. gregata was not present. The residue-filled mesh bags of each

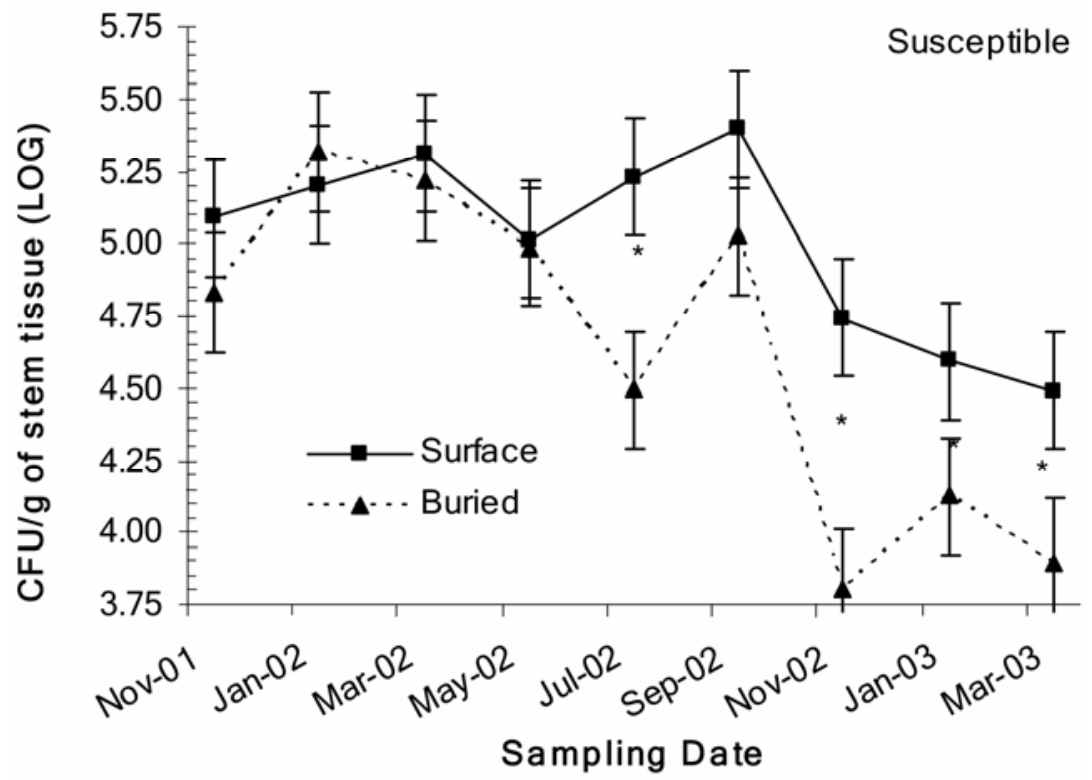

Fig. 1. Population density of Phialophora gregata in stem residue of the susceptible cultivar positioned on the soil surface or buried $20 \mathrm{~cm}$ below the soil surface. Population density was assessed by dilution plating ground stem tissue onto a semi-selective medium and counting colony forming units (CFU). Stems were sampled bimonthly from 15 November 2001 through 18 March 2003. Means at a sampling date with an asterisk $(*)$ are significantly different based on the difference between least square means $(P=0.03)$. Vertical bars represent standard error.

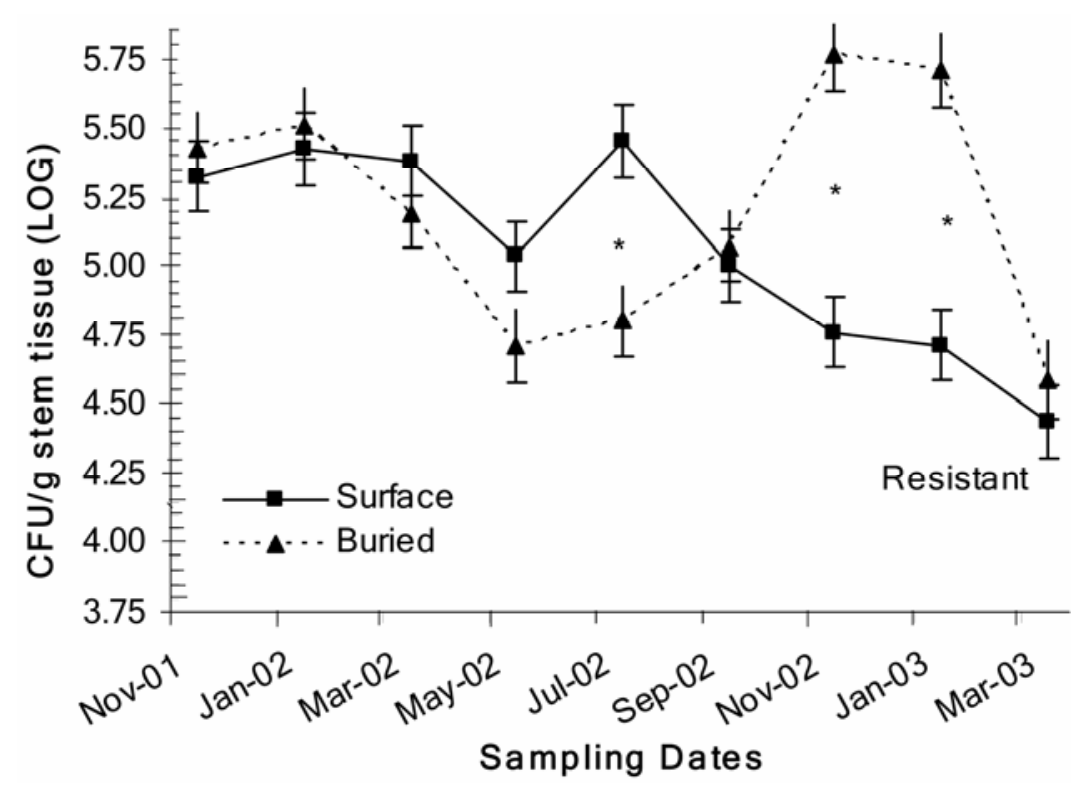

Fig. 2. Population density of Phialophora gregata in stem residue of the resistant cultivar placed on the soil surface or buried $20 \mathrm{~cm}$ below the soil surface. Population density was assessed by dilution plating ground stem tissue onto a semi-selective medium and counting colony forming units (CFU). Stems were sampled bimonthly from 15 November 2001 through 18 March 2003. Means at a sampling date with an asterisk $(*)$ are significantly different based on the difference between least square means $(P<0.0001)$. Vertical bars represent standard error. cultivar were assigned a random location in the plot and were secured with landscape pins. Stems of each cultivar were further assigned two treatments: (i) bags placed on the soil surface to simulate a no-till system, or (ii) bags buried $20 \mathrm{~cm}$ below the soil surface to simulate a conventional tillage system. Mesh bags were arranged in a randomized complete block design with $60 \mathrm{~cm}$ between treatments and a $1.5-\mathrm{m}$ border around the plot. Each combination of soybean cultivar and residue position treatment was replicated six times.

Nylon mesh bags were recovered from the plot and enclosed stems were assayed for the population density of $P$. gregata at 2-month intervals from 15 November 2001 to 18 March 2003. Recovered residue was assayed by allowing the sample stem residue to dry for $48 \mathrm{~h}$ followed by cutting 2 to $3 \mathrm{~cm}$ from each end of each of the six stems per nylon mesh bag. The stem residue was processed as previously described to determine population density of $P$. gregata, and remaining stems were replaced in the mesh bags and returned to their original locations.

Ground stem tissue of Corsoy 79 was assayed to determine the frequency of genotypes A and B in soybean stems bimonthly from November 2001 to March 2003. Ten subsamples of ground stem residue from each plot were placed in separate $2.0-\mathrm{ml}$ tubes. DNA of $P$. gregata was extracted from soybean stem residue using the FastDNA kit (Qbiogene/Bio101, Carlsbad, CA) according to a modified protocol (17). Samples were stored at $-20^{\circ} \mathrm{C}$ until assayed for genotypes A and B using polymerase chain reaction (PCR) primers and reaction protocols developed by Chen et al. (5).

Data were analyzed by comparing means using repeated measure ANOVA analysis with the Proc Mixed procedure of the SAS system (SAS Institute, Cary, NC). Mean comparisons were calculated by the differences of the least square means in Proc Mixed. A chi-squared analysis was used to determine whether the frequency of genotypes of $P$. gregata was affected by tillage type, reaction of soybean cultivar to $P$. gregata, or time of year.

\section{RESULTS}

Soybean cultivar and residue placement. The population density of $P$. gregata declined in stem residue of both cultivars $(P<0.0001)$ when the first and last sampling dates are compared regardless of residue placement (Figs. 1 and 2). However, the pattern of change was different for residue derived from the BSRsusceptible and -resistant cultivars and placement of the residue. The population density of $P$. gregata was greater $(P=$ 0.03 ) in surface residue of the susceptible cultivar compared with buried stem residue at the final sample date and at three of the 
four prior sampling dates (Fig. 1). The population density of $P$. gregata in residue on the soil surface remained constant during the last three sampling periods, while the population in buried residue declined rapidly starting at the September 2002 sampling date (Fig. 1).

The population density of $P$. gregata in buried and surface stem residue of the resistant cultivar was similar for the first 8 months of the experiment (Fig. 2). Following the six initial sampling periods, the population of $P$. gregata in buried residue of the resistant cultivar was greater than the surface residue from November 2002 through January 2003. However, the population density of $P$. gregata in residue of the resistant cultivar converged to no statistical difference at the conclusion of the experiment (Fig. 2).

Sampling date, position of residue, and soybean cultivar affected the population density of $P$. gregata. Buried stem residue of the resistant and susceptible cultivar supported differing population densities of the pathogen at some, but not all, sampling dates. The initial population density of $P$. gregata differed in buried residue of the two cultivars $(P=0.01)$ (Fig. 3$)$. Population densities in buried stems of both cultivars were similar from January 2002 to September 2002 , at which time populations increased significantly in the resistant cultivar but declined rapidly in the susceptible cultivar. This divergence in population density resulted in greater population density of $P$. gregata in the resistant cultivar, compared with the susceptible cultivar, in buried stem residue at the last three sampling dates (Fig. 3). The population density of $P$. gregata in stems of both cultivars on the soil surface did not differ statistically throughout the experiment (data not shown).

Population density and cultivars. Data for population densities of $P$. gregata in surface and buried stem residue were combined for each cultivar to determine the overall population of $P$. gregata in either resistant or susceptible stems. Stem residue derived from the BSR-resistant cultivar (Bell) and the BSR-susceptible cultivar (Corsoy 79) supported different population densities of $P$. gregata at sampling periods during the course of the experiment (Fig. 4). The population density of $P$ gregata declined for each cultivar during the 16month study, but the pattern of decline was different. The initial pathogen population was higher in the resistant cultivar than in the susceptible cultivar $(P<0.0001)$. During the ensuing 8 months, the population density declined but did not differ between cultivars (Fig. 4). Thereafter, the population density of $P$. gregata decreased sharply from November 2002 through March 2003 in the susceptible cultivar, while the pathogen population remained static for the resistant cultivar until January 2003 (Fig. 4). Thereafter, the pathogen population in the resistant cultivar declined sharply to a density similar to that of the susceptible cultivar at the end of the 16month study. Overall, the population density of $P$. gregata was higher at more sampling periods for the resistant cultivar.

Population density and residue placement. The population density of $P$. gregata declined during the course of the study regardless of residue placement, and the population density of $P$. gregata at the initiation of the experiment was significantly different $(P=0.02)$ from population densities observed at the final sample date (Fig. 5). The population density of $P$. gregata was not different in buried or surface stem residue except for the July 2002 sample period (Fig. 5).

Frequency of genotypes $A$ and $B$ of $P$. gregata. Stems of the susceptible cultivar

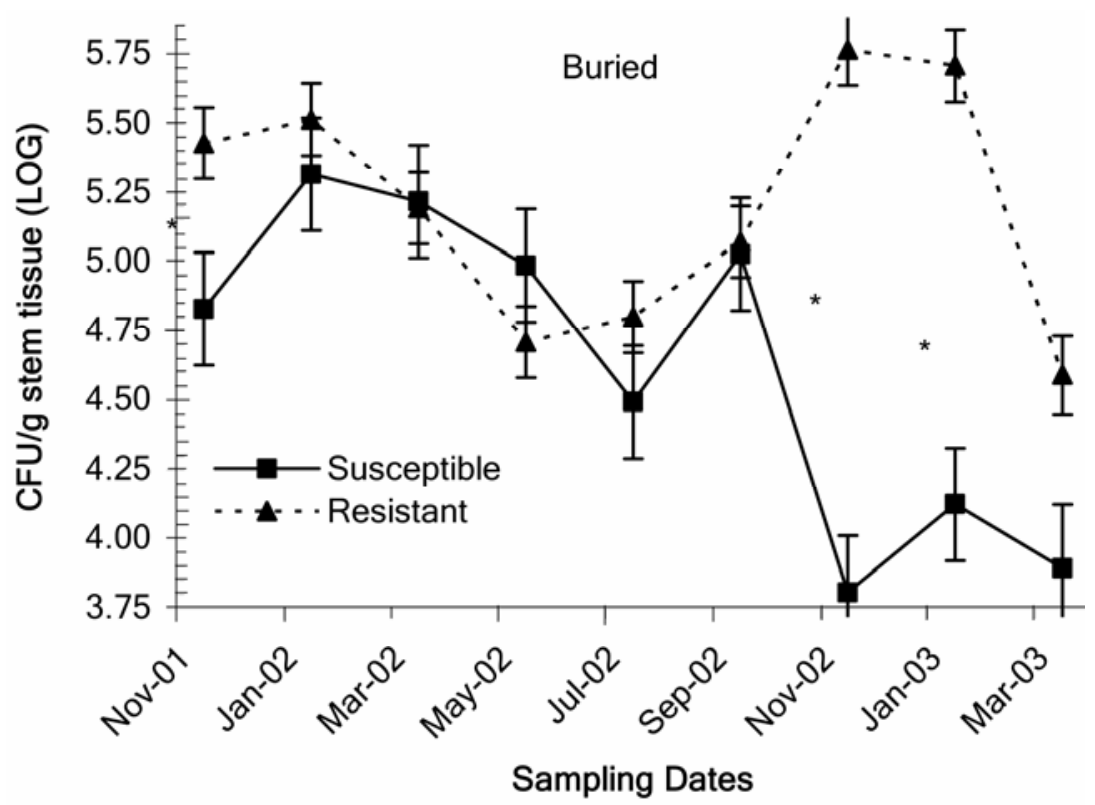

Fig. 3. Saprophytic population density of Phialophora gregata in stems of a resistant cultivar and a susceptible cultivar buried $20 \mathrm{~cm}$ below the soil surface. Stems were assayed for colony forming units (CFU) bimonthly from November 2001 through March 2003. Values are the mean of six replications from 15 November 2001 through 14 January 2003. Values are the mean of four replications for Corsoy 79 and five replications for Bell on 22 March 2003. Means at a sampling date with an asterisk (*) are significantly different based on the difference between least square means $(P<0.0001)$.

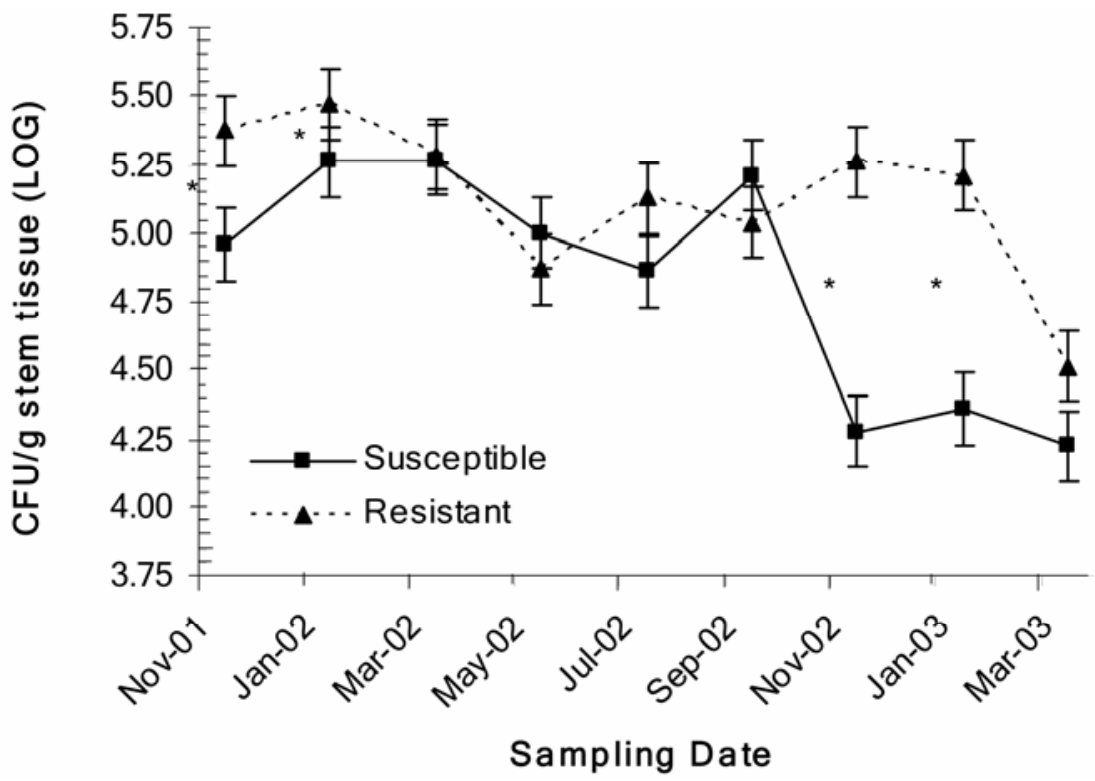

Fig. 4. Population density of Phialophora gregata in stems of a susceptible cultivar and a resistant cultivar sampled bimonthly from 15 November 2001 through 18 March 2003. Population density in stem residue of each cultivar was assessed by dilution plating ground stem tissue onto a semi-selective medium and counting colony forming units (CFU). Data are combined for placement of residue, and means at a sampling date with an asterisk (*) are significantly different based on the difference between least square means $(P<0.0001)$. Vertical bars represent standard error. 
were assayed for specific genotypes of $P$. gregata. Both genotype A and B were detected in some samples, and therefore, the frequency of detection of genotype A and $B$ may be greater than the sample size (Table 1). The initial ratio of genotype $B$ to A was 1.4:1.0 (Table 1). The ratio of genotypes changed during the course of the experiment. $P$. gregata was detected in $83 \%$ of stems, regardless of residue position, during the course of the experiment. Of the stems PCR positive for P. gregata, genotype B was detected in $63 \%$, while genotype A was detected in $20 \%$ of the stems. Genotype B of $P$. gregata was more frequently detected at all sampling dates than genotype A when data were combined for surface residue and buried residue (Table 1). Genotype B was the predominant genotype detected in residue in March 2002 and May 2002. Genotype A was either not detected or had a low frequency of detection in March 2002 and May 2002 in surface and buried residue, but was detected at a high frequency in surface residue in July 2002. Genotypes A and B were detected at the conclusion of the experiment in March 2003 (Table 1).

When data were pooled for each sampling date, P. gregata was detected in $99 \%$ of stems that were positioned on the soil surface and in $64 \%$ of buried stems. Genotype B was detected at a significantly higher frequency than $\mathrm{A}$ in both surface and buried residue. Genotype B of P. gregata was detected at a frequency of $85 \%$ in soil surface stems and $41 \%$ in buried stems $(P=0.005)$. Genotype A was detected at a frequency of $23 \%$ in buried residue and $17 \%$ in surface residue.
Time of year affected the frequency of detection of genotype $\mathrm{B}$ in stems on the surface and buried residue. Genotype B was detected in $94 \%$ of stems on the soil surface in the summer and $80 \%$ of stems on the soil surface in winter (Fig. 6). Frequency of detection of genotype B in buried stem residue was also significantly greater in summer than winter (Fig. 6).

\section{DISCUSSION}

The population density of $P$. gregata in soybean stem residue was affected by origin of residue, BSR-resistant or -susceptible soybean cultivar, and placement of soybean residue. Previous research has reported less colonization of $P$. gregata in stems of resistant cultivars than of susceptible cultivars at the end of the parasitic phase (20). However, in the current study, the resistant cultivar had a slightly higher initial population density of $P$. gregata than the susceptible cultivar. This was an unexpected result because residue was collected from a field where symptom severity was greater for the susceptible cultivar Corsoy 79 compared with the resistant cultivar Bell. Lower symptom severity associated with resistant cultivars, based on apparent decay of internal stem tissues, may have provided a better nutritional substrate for saprophytic growth of the pathogen compared with stems of a susceptible cultivar, with substantial rotting of stem tissues. We conclude that $P$. gregata is a better saprophyte in soybean stems that are less decayed during the parasitic phase of the pathogen. Thus, the severity of symptoms expressed by soybean during the pathogen's parasitic phase may not predict sap-

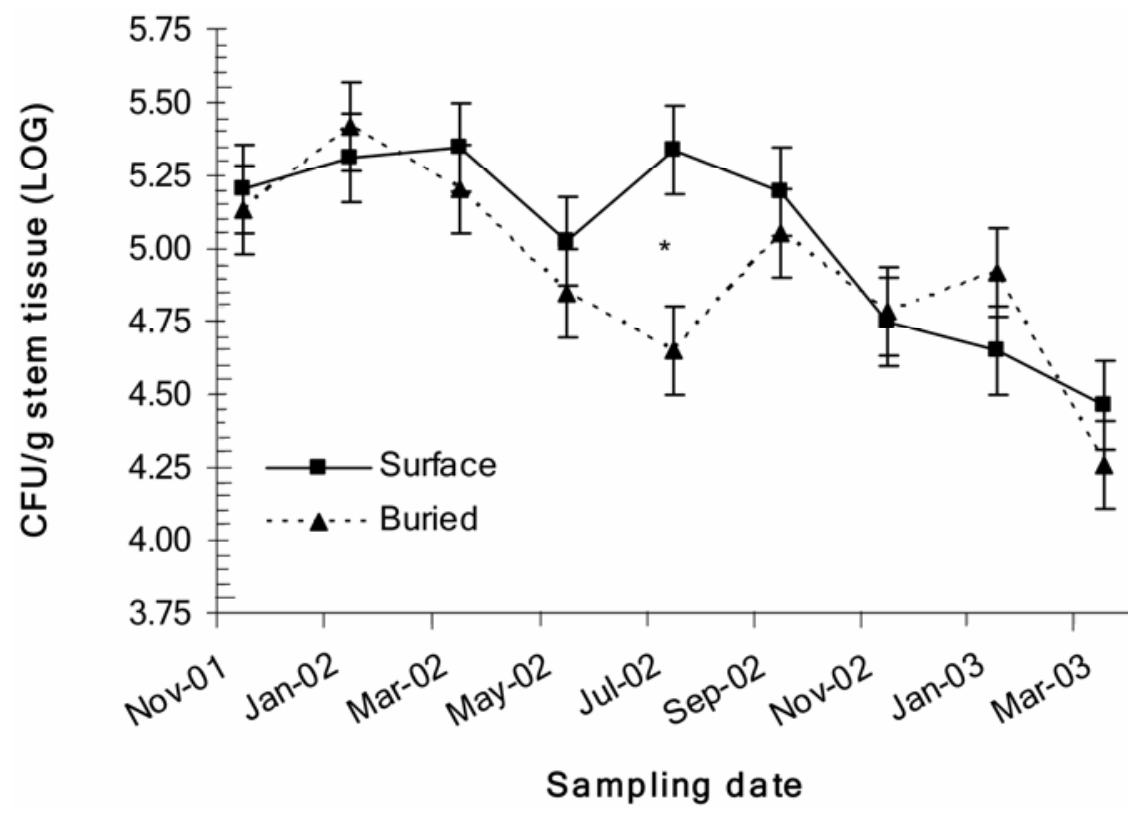

Fig. 5. Population density of Phialophora gregata in stem residue of a resistant cultivar and a susceptible cultivar positioned on the soil surface or buried $20 \mathrm{~cm}$ below the soil surface. Stem tissue was assayed for population density of P. gregata bimonthly from 15 November 2001 to 18 March 2003 . Each treatment was replicated six times. Data are combined for soybean cultivar, and means at a sampling date with an asterisk $(*)$ are significantly different based on the difference of least square means $(P=0.02)$. Vertical bars represent standard error. rophytic survival. However, we studied only one source of resistance, and other sources of resistance may or may not show similar results. Furthermore, resistance to $P$. gregata during the parasitic phase of the pathogen may function independently of its saprophytic phase. Bell, the resistant soybean cultivar, has a history of low symptom severity in field trials (15), but supporting reproduction by the pathogen comparable to the susceptible cultivar in this current study (A. E. Kinziger, unpublished data). Limiting reproduction of the pathogen is important for preventing high population densities of $P$. gregata in subsequent years. Data from previous studies support the concept that crop rotation and resistant cultivars effectively reduce the pathogen population density and inoculum potential in soil $(1,19,20)$. The current study suggests that the length of crop rotation sequences required to lower inoculum of $P$. gregata would be the same for susceptible and resistant soybean cultivars.

Buried stem residue and surface residue in this experiment simulated conventional till and no-till management systems, respectively. We observed that the population

Table 1. Detection of genotypes A and B of Phialophora gregata in stems $(n=120)$ of a susceptible cultivar positioned on or below the soil surface

\begin{tabular}{|c|c|c|c|}
\hline \multirow{2}{*}{$\begin{array}{l}\text { Sampling date } \\
\text { Residue position }\end{array}$} & \multicolumn{3}{|c|}{ No. positive samples } \\
\hline & $\mathbf{A}$ & B & $\chi^{2^{\mathrm{a}}}$ \\
\hline \multicolumn{4}{|l|}{ November-01 } \\
\hline Buried & 50 & 38 & 15.5 \\
\hline Soil surface & 20 & 60 & 33.3 \\
\hline Total & 70 & 98 & 48.8 \\
\hline \multicolumn{4}{|l|}{ January-02 } \\
\hline Buried & 30 & 10 & 13.3 \\
\hline Soil surface & 0 & 60 & 60.0 \\
\hline Total & 30 & 70 & 73.3 \\
\hline \multicolumn{4}{|l|}{ March-02 } \\
\hline Buried & 0 & 10 & 43.3 \\
\hline Soil surface & 0 & 40 & 33.3 \\
\hline Total & 0 & 50 & 76.7 \\
\hline \multicolumn{4}{|l|}{ May-02 } \\
\hline Buried & 2 & 60 & 56.1 \\
\hline Soil surface & 2 & 60 & 56.1 \\
\hline Total & 4 & 120 & 112.3 \\
\hline \multicolumn{4}{|l|}{ July-02 } \\
\hline Buried & 1 & 39 & 30.7 \\
\hline Soil surface & 26 & 60 & 30.5 \\
\hline Total & 27 & 99 & 61.3 \\
\hline \multicolumn{4}{|l|}{ September-02 } \\
\hline Buried & 10 & 10 & 26.7 \\
\hline Soil surface & 10 & 50 & 26.7 \\
\hline Total & 20 & 60 & 53.3 \\
\hline \multicolumn{4}{|l|}{ November-02 } \\
\hline Buried & 0 & 10 & 43.3 \\
\hline Soil surface & 0 & 40 & 33.3 \\
\hline Total & 0 & 50 & 76.7 \\
\hline \multicolumn{4}{|l|}{ January-03 } \\
\hline Buried & 20 & 30 & 3.3 \\
\hline Soil surface & 20 & 40 & 6.7 \\
\hline Total & 40 & 70 & 10.0 \\
\hline \multicolumn{4}{|l|}{ March-03 } \\
\hline Buried & 9 & 11 & 26.7 \\
\hline Soil surface & 10 & 40 & 16.7 \\
\hline Total & 19 & 51 & 43.4 \\
\hline
\end{tabular}

${ }^{a}$ Chi-square; $P=0.05$. 
density of $P$. gregata in surface stem residue of the susceptible cultivar was significantly higher than in buried stems, which correlates with previous reports (2). Buried stem residue of the resistant cultivar, however, continued to support an increasing population density of $P$. gregata 365 days after the initiation of the experiment, which is inverse from previous studies (2). However, the population density in buried and surface residue at the end of the study was the same. The population density of $P$. gregata remained high and stable in buried residue of the resistant cultivar for 16 months compared with a sharp decline in the population density of $P$. gregata in the susceptible cultivar after 11 months. The population density in stem residue on the soil surface in winter 2001-02 was greater than the population density in May 2002. Previous research has also demonstrated that the population density and sporulation was greater in the cool months and at low temperatures $(2,7)$. Research conducted by Adee et al. (2) also indicates the population density in stems on the soil surface remained constant approximately 400 days after initiation of the experiment. Similarly, our data indicate the population density appears to stabilize 360 days after the initiation of the experiment.

A 1.0:3.2 ratio of genotype A to $B$ in Corsoy 79 is unlike previous reports that suggest susceptible cultivars have a ratio skewed toward genotype A $(5,16)$. Residue of Corsoy 79 used in our study originated from a field naturally infested with $P$. gregata. The severities of foliar and stem symptoms for Corsoy 79 grown in this field were 42 and $71 \%$, respectively, in 2001. High foliar symptom severity would suggest a greater proportion of genotype A, since genotype A causes greater foliar symptom severity than genotype B (9). However, Kinziger and Grau (11) observed that plants inoculated with a 1:9 ratio of A:B expressed foliar symptom severities comparable to plants inoculated with genotype A only in greenhouse trials. The field where the collected stems originated may have had a greater population density of genotype B than of A in the soil. An assessment of the population of genotypes A and B of $P$. gregata in the soil would be a valuable future research project.

Genotype B of $P$. gregata was detected at a higher frequency than genotype A. These data suggest that genotype B is a better saprophyte than genotype A in soybean residue. Unpublished data have indicated that over time genotype B of P. gregata in a naturally infested field is more prevalent than genotype A (C. R. Grau, personal communication). However, recent study indicates that genotype A is detectable after 5 years of corn (22). A point to consider is the collection of soybean stems from a single geographic location, and the frequency of genotypes of $P$. gregata may vary by location $(5,16)$.

Genotype B of $P$. gregata was detected more frequently in susceptible soybean stems on the soil surface than in buried stems, while genotype A was detected more frequently in soybean stems buried in the soil than on the soil surface. No-till fields that have had a high frequency of detection of genotype B from soybean stems may benefit from practicing a conventional tillage regime that would not only decrease the amount of genotype B, but would also decrease the amount of $P$. gregata in the system. Although no-till fields are profitable for many growers, pathogens such as $P$. gregata that survive in plant residue benefit from the lack of

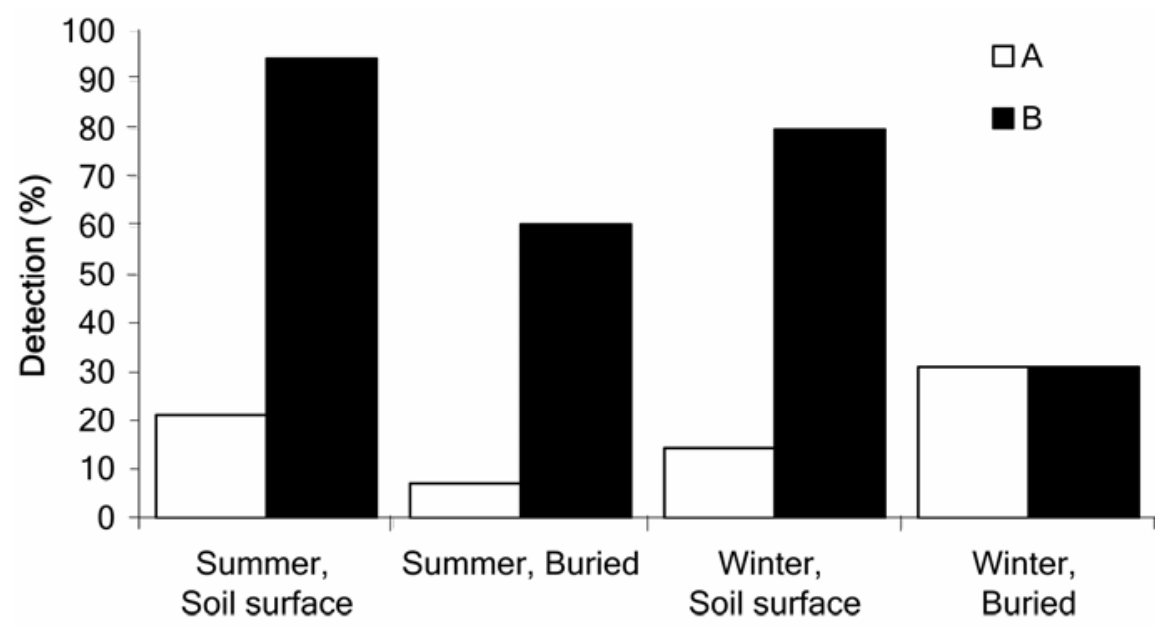

Season and residue position

Fig. 6. Proportion of genotypes A and B of Phialophora gregata in stems of a brown stem rot susceptible cultivar placed at two different soil positions from November 2001 through March 2003. Proportion of genotypes A and B were determined for the summer months of May, July, and September 2001 and winter months of November 2001, January, March, and November 2002, and January and March 2003. Chi-square analysis was used to determine whether the frequency of pathogen genotypes differed at each sampling date $(P<0.005)$. decay of organic matter that remains on the soil surface.

Results from this current study are the first to determine that genotypes of $P$. gregata change in frequency in stem residue in the absence of a soybean crop. Genotype A had a low frequency of detection in stem residue in spring, while genotype B had a high frequency of detection during the same period. The high proportion of genotype B recovered from stems of Corsoy 79 was atypical based on previous studies. Chen et al. (5) and Malvick et al. (16) reported a greater proportion of genotype A than of genotype B in stems of susceptible cultivars at harvest maturity. However, they did not assay stem residue that had overwintered.

Future studies on P. gregata should address the dynamics of population density and pathogen genotype in both soil and stem residue. Results of such studies would provide guidance to develop strategies to breed soybeans for resistance to $P$. gregata and the deployment of resistant cultivars to manage BSR. Such studies are more possible because of advances in development of molecular markers to identify specific genotypes of $P$. gregata $(5,8,16)$, and methods to use PCR to quantify the amount of $P$. gregata DNA in soil and stem tissue.

\section{ACKNOWLEDGMENTS}

We thank Tristan Mueller and Paul Rabedeaux for assisting burying and excavating mesh bags throughout the experiment, especially during the winter months; Marcus Vinje for help with DNA extractions and PCR; the lab of D. K. Malvick at the University of Illinois Champaign-Urbana for sharing DNA extraction protocols; and Julie Meyer for critical review of this manuscript.

\section{LITERATURE CITED}

1. Adee, E. A., Grau, C. R., and Oplinger, E. S. 1995. Inoculum density of Phialophora gregata related to severity of brown stem rot and yield of soybean in microplot studies. Plant Dis. 79:68-73.

2. Adee, E. A., Grau, C. R., and Oplinger, E. S. 1997. Population dynamics of Phialophora gregata in soybean residue. Plant Dis. 81:199203.

3. Adee, E. A., Oplinger, E. S., and Grau, C. R. 1994. Tillage, rotation sequence, and cultivar influences on brown stem rot and soybean yield. J. Prod. Agric. 7:341-347.

4. Allington, W. B., and Chamberlain, D. W. 1948. Brown stem rot of soybean. Phytopathology 38:793-802.

5. Chen, W., Grau, C. R., Adee, E. A., and Meng, X.-Q. 2000. A molecular marker identifying subspecific populations of the soybean brown stem rot pathogen, Phialophora gregata. Phytopathology 90:875-883.

6. Gray, L. E., and Grau, C. R. 1999. Brown stem rot. Pages 28-29 in: Compendium of Soybean Diseases. 4th ed. G. L. Hartman, J. B. Sinclair, and J. C. Rupe, eds. American Phytopathological Society, St. Paul, MN.

7. Hamilton, R. I., and Boosalis, M. G. 1955. Asexual reproduction in Cephalosporium gregatum. Phytopathology 45:293-294.

8. Harrington, T. C., Steimel, J., Workneh, F., and Yang, X. B. 2003. Characterization and distribution of two races of Phialophora gregata in 
the North-Central United States. Phytopathology 93:901-912.

9. Hughes, T. J., Chen, W., and Grau, C. R. 2002. Pathogenic characterization of genotypes A and B of Phialophora gregata f. sp. sojae. Plant Dis. 86:729-735.

10. Hughes, T. J., Kurtzweil, N. C., Diers, B. W., and Grau, C. R. 2004. Resistance to brown stem rot in soybean germ plasm with resistance to the soybean cyst nematode. Plant Dis. 88:761-768.

11. Kinziger, A. E., and Grau, C. R. 2002. Coinoculation of genotypes $\mathrm{A}$ and $\mathrm{B}$ of Phialophora gregata does not modify symptom expression of soybean. (Abstr.) Phytopathology 92:S42.

12. Lai, P. Y. 1968. Isolation of Cephalosporium gregatum from soybean straw. Phytopathology 58:1194-1195.

13. Lai, P. Y., and Dunleavy, J. M. 1969. Sporulation of Cephalosporium gregatum on naturally infested soybean straw. Phytopathology 59:343-345.

14. Lund, M. G., Carter, P. R., and Oplinger, E. S. 1993. Tillage and crop rotation affect corn, soybean, and winter wheat yields. J. Prod. Agric. $6: 207-213$.

15. MacGuidwin, A. E., Grau, C. R., and Oplinger,
E. S. 1995. Impact of planting 'Bell', a soybean cultivar resistant to Heterodera glycines, in Wisconsin. J. Nematol. 27:78-85.

16. Malvick, D. K., Chen, W., Kurle, J. E., and Grau, C. R. 2003. Cultivar preference and genotype distribution of the brown stem rot pathogen Phialophora gregata in the midwestern United States. Plant Dis. 87:1250-1254.

17. Malvick, D., and Grunden, E. 2005. Isolation of fungal DNA from plant tissues and removal of DNA amplification inhibitors. Mol. Ecol. Notes 5:958-960.

18. Mengistu, A., and Grau, C. R. 1986. Variation in morphological, cultural, and pathological characteristics of Phialophora gregata and Acremonium sp. recovered from soybean in Wisconsin. Plant Dis. 70:1005-1009.

19. Mengistu, A., Grau, C. R., and Gritton, E. T. 1986. Comparison of soybean genotypes for resistance to and agronomic performance in the presence of brown stem rot. Plant Dis. 70:1095-1098.

20. Mengistu, A., Tachibana, H., and Grau, C. R. 1991. Selective medium for isolation and enumeration of Phialophora gregata from soybean straw and soil. Plant Dis. 75:96-99.

21. Patzoldt, M. E., Grau, C. R., Stephens, P. A., Kurtzweil, N. C., Carlson, S. R., and Diers, D.
W. 2004. Localization of a quantitative trait locus providing brown stem rot resistance in the soybean cultivar Bell. Crop Sci. 45:1241-1248

22. Pedersen, P. 2002. Yield potential of soybean under various management conditions. Ph.D. diss. University of Wisconsin-Madison.

23. Suffling, R., and Smith, D. W. 1974. Litter decomposition studies using mesh bags: Spillage inaccuracies and the effects of repeated artificial drying. Can. J. Bot. 52:2157-2163.

24. Tachibana, H., Epstein, A. H., and Havlovic, B. J. 1989. Effects of four years of continuous cropping of maturity group II soybeans resistant to brown stem rot on brown stem rot and yield. Plant Dis. 73:846-849.

25. Waller, R. S., Nickell, C. D., and Gray, L. E. 1992. Environmental effects on the development of brown stem rot in soybean. Plant Dis. 76:454-457

26. Workneh, F., Yang, X. B., and Tylka, G. L. 1999. Soybean brown stem rot, Phytophthora sojae, and Heterodera glycines affected by soil texture and tillage relations. Phytopathology 89:844-850.

27. Wrather, J. A., Stienstra, W. C., and Koenning, S. R. 2001. Soybean disease loss estimates for the United States from 1996 to 1998. Can. J. Plant Pathol. 23:122-131. 